\title{
The Ifo Business Cycle Clock: Circular Correlation with the Real GDP
}

\author{
Klaus Abberger \\ Wolfgang Nierhaus
}

\author{
CESIFO WORKING PAPER NO. 3179 \\ CATEGORY 12: EMPIRICAL AND THEORETICAL METHODS \\ SEPTEMBER 2010
}
An electronic version of the paper may be downloaded
- from the SSRN website:
- from the RePEc website:
www.SSRN.com
www.RePEc.org
- from the CESifo website:
www.CESifo-group.org/wp




\title{
The Ifo Business Cycle Clock: Circular Correlation with the Real GDP
}

\begin{abstract}
The Ifo Business Climate is the most important indicator for the business cycle in Germany. In 1993 the connection between the two components of the business climate - business situation and business expectations - was graphically portrayed by Ifo in a 4-quadrant scheme: the Ifo Business Cycle Clock. Today similar monitoring systems are firmly established and are presented by Eurostat, the OECD and others. The German Federal Statistical Office presents the real GDP in a 4-quadrant scheme. In the following, important qualities of the Ifo Business Cycle Clock are shown. The importance of orthogonal functions for the circular correlation is examined.
\end{abstract}

JEL-Code: E32, C32, C39, C22.

Keywords: Ifo business climate, growth cycle, circular correlation, linear-circular correlation, temporal disaggregation.

Klaus Abberger

Ifo Institute for Economic Research at the

University of Munich

Poschingerstrasse 5

81679 Munich

Germany

abberger@ifo.de
Wolfgang Nierhaus

Ifo Institute for Economic Research at the

University of Munich

Poschingerstrasse 5

81679 Munich

Germany

nierhaus@ifo.de 


\section{Introduction}

Business cycle indicators are meant to describe cyclical economy activity in market-economy systems in a timely and accurate fashion. The characteristic of a good indicator is that it signals turning points in economic activity in a timely and clear fashion (i.e. without false alarms). In addition the lead of the indicator should be stable so that a relatively reliable estimate can be made as to how early the signal of the indicator occurs. Finally, the results should be available in a timely manner and not subject to any major revisions after publication (see Abberger and Wohlrabe, 2006, p.19).

An especially reliable indicator for the development of economic activity in Germany is the Ifo Business Climate that was developed by the Ifo Institute in the mid-1960s on the basis of the monthly company survey, the Ifo Business Survey (see Abberger and Nierhaus 2007). The business climate is determined according to the formula $[(\mathrm{BS}+200)(\mathrm{BE}+200)] 1^{12}-200$, whereby BS designates the percentage balance of the positive and negative responses regarding the current business situation and $\mathrm{BE}$ the percentage balance of the positive and negative responses for the business outlook in the next six months. With the geometrical average the fluctuations of the Ifo Business Climate in cases of extreme values are dampened slightly in comparison with an arithmetic average. The two climate components reflect the current situation (the business situation is good/ satisfactory/ poor) and the outlook (the business situation is likely to be more favourable/ about the same/ somewhat more unfavourable) of the surveyed businesses. The questions have been combined by the Ifo Institute in order to show the cyclical situation from which a specific anticipation is reported. Hence, a firm's anticipation "will remain about the same" in a boom phase has a different meaning than in a recession, i.e. a continuation of the boom or a continuation of the recession.

The Ifo Business Climate was published for the first time in 1971, but initially only for manufacturing. On year later the business climate data for the survey sectors manufacturing, construction, wholesaling and retailing were combined to form the indicator in its present form (Ifo Business Climate for German Industry and Trade). The four quadrant scheme for the cyclical relationship of business situation and business expectations from the Ifo Business Survey was published for the first time in spring 1993. Initially the variables in the economic cycle moved counter clockwise due to the arrangement of the axes (see Leibfritz and Nierhaus 1993). The present quadratic depiction of the Ifo Business Cycle Clock, in which the direction of the business situation and expectations move in the conventional clockwise direction, was introduced in 1999 (see Abberger and Nierhaus 2008b).

This article will examine the connections between the Ifo Business Cycle Clock for German Industry and Trade and the quarterly Business Cycle Monitor for the Real GDP developed by 
the German Federal Statistical Office. The GDP Business Cycle Monitor is an additional, modern monitoring system that is able to depict the developments of total economic activity in a four quadrant scheme (see Oltmanns 2009). In this article the two monitoring concepts will be described. Then the inputted series of the two systems will be examined for linear correlation. This is followed by a discussion of the importance of orthogonal functions for the subsequent circular analysis. This is done, first of all, by a visual examination of the two four-quadrant schemes. By using the statistical procedure of circular correlation we then examine whether the cyclical movements of the Ifo Business Cycle Clock and the GDP Business Cycle Monitor display statistically significant similarities. Then the selectivity of the Ifo Business Cycle Clock is examined with regard to the classification of basic economic phases - upturns/downturns - by means of an error display. Finally the linear circular correlation between the Ifo Business Cycle Clock and the cyclical components of real GDP is discussed. This analysis is carried out using monthly values; the monthly GDP values needed for the analysis were derived from the official quarterly results by means of the temporal disaggregation methods developed by Chow \& Lin.

\section{The Ifo Business Cycle Clock}

Business cycles can be defined on the basis of fluctuations in cyclically relevant variables over the course of time. A two-phase division of cycles consists of an expansion and a contraction phase, with the two phases being connected with each other by lower and upper turning points. Figure 1 shows how an artificially constructed business climate and its two components - business situation and business expectations - ideally move. As the coincidental parameter for the economic situation in the overall economy, the business situation indicator is used, whose cyclicality is described by a two-year sine-wave oscillation. The expectation indicator anticipates the situation indicator by precisely six months; the business climate as the average of the situation and the expectations thus has constant lead of three months over the business situation. 
Fig. 1

\section{Business Cycle ${ }^{1)}$ : Assessment of Current Business Situation, Business Expectations and Business Climate}

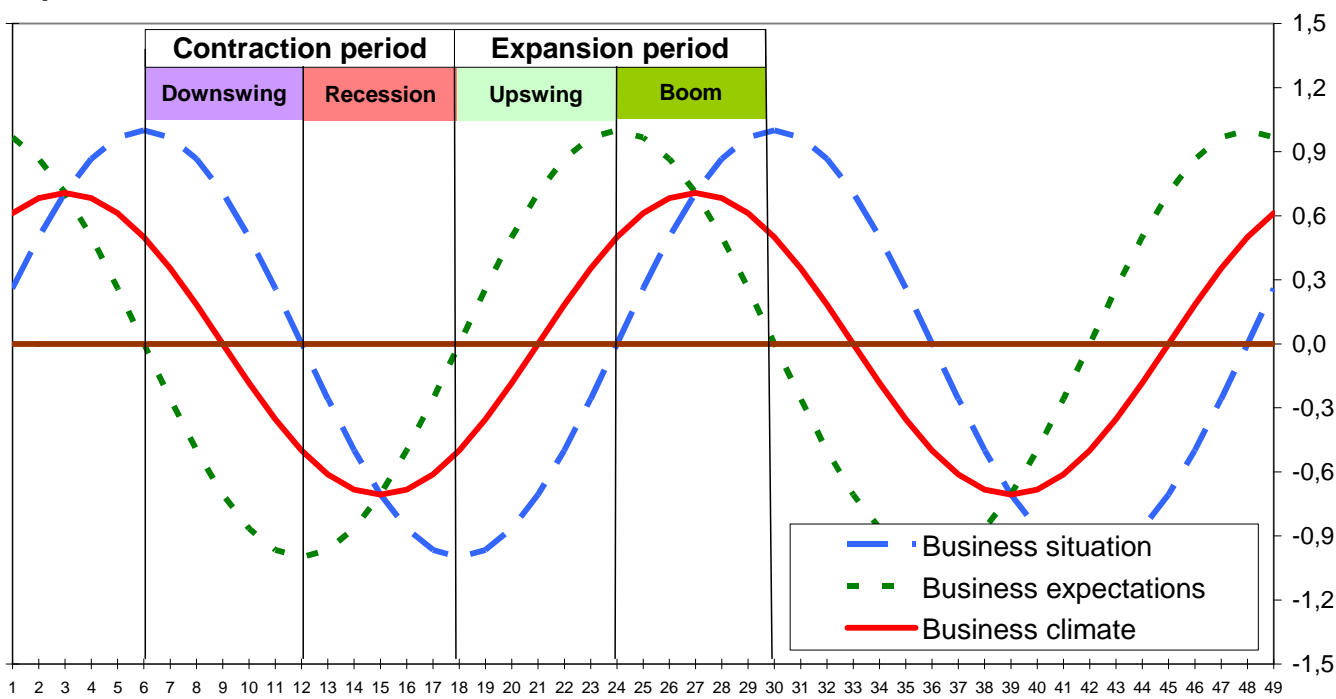

1) Two year sine-wave fluctuation. Lead of business expectations over business situation: 6 months.

The economic expansion phase - measured by the course of the situation indicator - extends from a lower turning point to an upper turning point. After having passed through the lower turning point, the business situation improves, but is still initially poor on balance (i.e., negative). Only have having passed the zero balance does the business situation become good, on balance (i.e., positive). The two sub-phases can be labelled upswing and boom. The economic contraction phase extends from an upper turning point to a lower turning point. Also here two sub-phases can be distinguished and assigned labels: downturn and recession. ${ }^{1}$ In the downturn the business situation worsens, but on balance is still good (i.e., positive). In recession with further worsening the business situation is poor on balance, i.e., negative. Since the company responses regarding the business situation and the business expectations are not subject to a trend, all four business cycle phases are identical in this ideal-typical example, with the assumed two-year sine-wave oscillation, are equally long: precisely six months.

The basic idea of the Ifo Business Cycle Clock is to assign the business situation (good/satisfactory/poor) at every point in time to the respective business expectations reported by the companies (more favourable/about the same / more unfavourable). On the abscissa of the business cycle clock the situation indicator is placed; on the ordinate the corresponding value of the expectation indicator. The diagram is divided into four quadrants by means of the cross-

1 This term "recession" is employed here to designate a specific combination of situation and expectations. This does not correspond to the usual definition of a recession in the real economy. For a discussion on the concept of recession, see Abberger and Nierhaus (2008a). 
hairs of the two zero lines that mark, in terms of the course of the business situation, the four sub-phases of the business cycle: upswing, boom, downturn, recession (see Fig. 2).

The assessments of the surveyed companies for the business situation and for the business expectations are poor, on balance, i.e., in minus, the business cycle is in "recession" (lower left quadrant). When the expectation indicator moves into plus territory (with an improving but still on balance poor business situation), the indicator moves into the upswing phase (upper left quadrant). If both the business situation and business expectations are good on balance, that is in plus, there is a "boom" (upper right quadrant). If the expectation indicator turns into minus territory (with a worsening but still on balance good business situation), a downturn sets in (lower right quadrant). Since the expectation indicator leads the situation indicator systematically by exactly sixth months in a business cycle totally two years, the business cycle in this diagram moves in a clockwise direction. In doing so, the situation-expectation graph cuts the abscissa of the business cycle clock when it reaches the maximum or minimum of the business situation (upper and lower economic turning points). The ordinate of the clock is cut when the business situation reaches the zero balance "from below" or "from above".

The phase-division of the business cycle clock can also be anchored on another business survey series. If one uses for example the business climate indicator as a central reference series, which in the chosen example has a lead of three months over the situation indicator, the empirical borderlines for the four cyclical phases of the business cycle clock would turn by $45^{\circ}$ in a counterclockwise direction. ${ }^{1}$ The upper or the lower turning points of the business cycle (defined here as local maximum or minimum of the business climate) is now ideal-typically on the diagonal that connects the corner-point of the lower left quadrant with the corner-point of the upper right quadrant. On the second main diagonal of the clock that connects the two other corners of the clock, are the zero balances of the business climate. The individual phases of the business cycle are now within the four triangles that are formed by the two diagonals and their intersection point in the centre of the clock (upswing in the left triangle, boom in the upper triangle, downturn in the right triangle, recession in the lower triangle). There would be yet another phase division if the expectation indicator was used as a reference series.

1 For an empirical argumentation for this alternative quadrant division, see Abberger (2005). 
Fig. 2

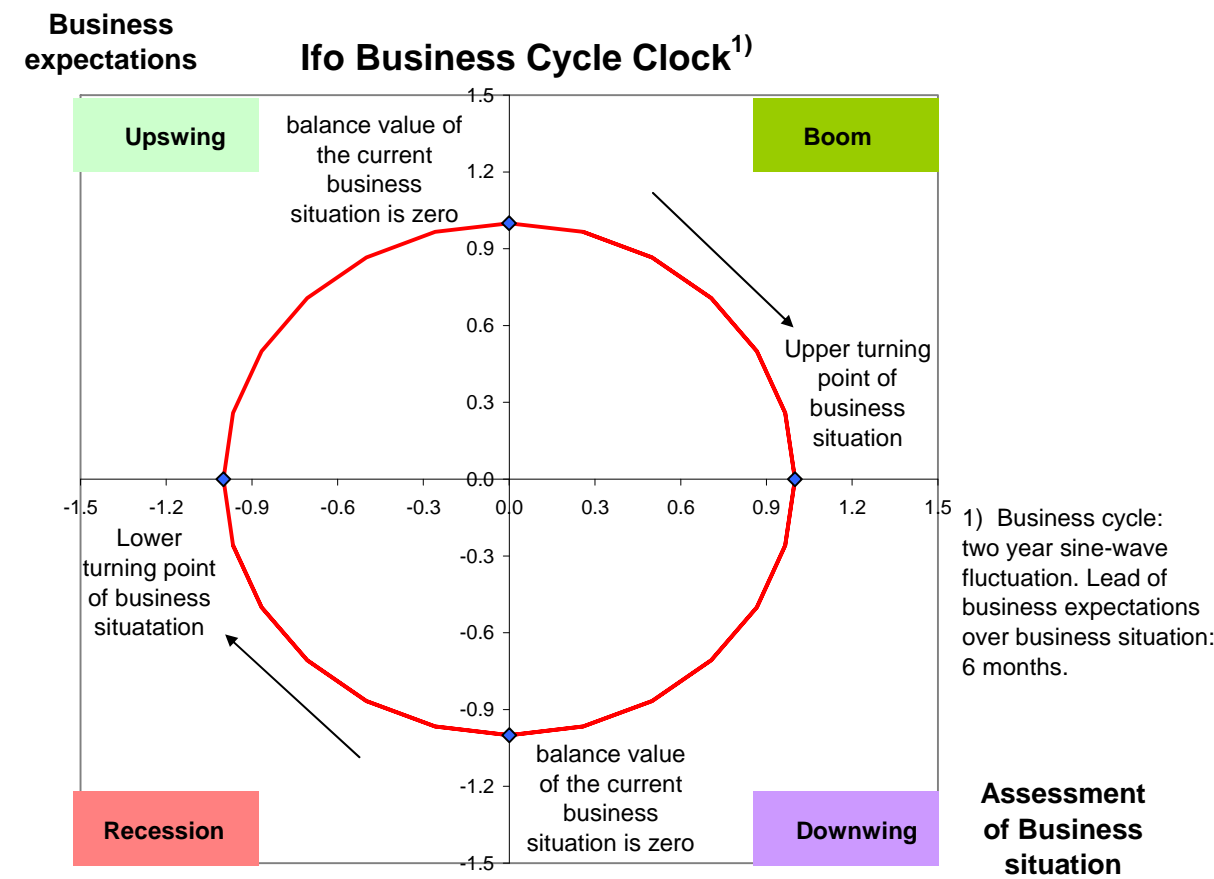

Empirically the relationship tends to be somewhat less stringent than what we have in the idealtypical representation of the business cycle clock - modelling of the cycle via a constant 24month sine-wave oscillation, exact anticipation of the situation indicator by means of the expectation indicator with a stable course of precisely six months. The exact circular course of the business cycle clock results, in this example, because the two chosen indicator functions stand orthogonally to each other. The length of the business cycle in Germany and in other industrialised countries, however, is considerably longer that the two year period chosen here as a model. In this case the empirically observed course of the expectation indicator vis-à-vis the situation indicator is not large enough that the two curves are orthogonal to each other. This can distort the rotation of the clock into an elliptical movement.

Moreover, short-term irritations in the firms' assessment formations, erroneous appraisals, asymmetric response behaviour, sampling errors, etc. can result in unsystematic movements of the situation-expectation graphs within and between the individual quadrants of the business cycle clock that cover up the actual cyclical movement and can even cause a temporary reverse movement. This would correspond to the case of adaptive expectations. With rational expectations the usual course of the expectations sets in and the Ifo Business Cycle Clock runs clockwise. 
A further basis for a systematic deviation from the circular process results from the different types of the two indicators. While the survey question on the business situation is a matter of its current level, the business expectations are surveyed in terms of changes over the previous survey. In purely mechanical terms this has two effects that counteract each other: the changes that are expressed in the expectations can cumulate to those of the situation appraisal. If, for example, in one month 100 survey participants expect a more unfavourable business situation, and in the following month 100 again give this response, then it can be the case that a total of 200 companies have revised their situation assessments downwards. Conversely, not every reported change must result in an adjustment of the business situation. Thus, a favourable business situation can develop more unfavourably but nevertheless remain good, having become merely less favourable. Also a poor business situation can become even more unfavourable and continue to be poor. These considerations show that the situation indicator and the expectations indicator can have differently strong spikes.

In terms of erratic disturbances in the movement of the clock, it is the case that the irregular components of the initial series are weakly marked in comparison with the smooth trend business-cycle components. The MCD measurement for the situation indicator amounts to two months, but for the somewhat less volatile expectation indicator only one month. The MCD measurement shows the point at which the change of the smooth component of a series outweighs the irregular movement, on average. It indicates the average delay before one can be relatively sure that directional changes of indicators are not of erratic nature but are due to cyclical factors (see Abberger and Nierhaus 2009, 17).

\section{The GDP-Business Cycle Monitor}

In recent years various graphical monitoring systems that display the cyclical component of selected indicators and their modification (vis-à-vis the previous period) in a 4 quadrant scheme have been developed in Europe. These include the Economic Climate Tracer developed by Gayer, the Business Cycle Tracer of the Central Statistical Office of the Netherlands, the European Business Cycle Clock of Eurostat, the OECD Business Cycle Clock as well as the Business Cycle Monitor of the German Federal Statistical Office. ${ }^{1}$ These monitoring systems focus primarily on the cyclical component of sector-specific or macroeconomic indicators of the official statistics. They also use business and consumer surveys. The trend adjustment necessary for the extraction of the cyclical component is done with the help of statistical filter procedures. The direction of the cyclical component depends on the filter used.

1 See Gayer (2010), Ruth, Schouten and Wekker (2005), Eurostat (2010), OECD (2010), Federal Statistical Office (2010). 
In the following, the business cycle monitor will not be presented on the sectoral level but in the more comprehensive context of the system of national accounts (Abberger and Nierhaus 2010a). Following a Study of the German Federal Statistical Office (Oltmanns 2009), a business cycle monitor for real GDP in Germany will be presented and analysed. In modern business cycle theory, business cycles are defined primarily as variations of the utilisation degree of the production potential. If the trend of GDP is interpreted as a non-structural estimate of the production potential, the phase in the business cycle can be equivalently identified by means of the deviation of real GDP from its trend (cyclical component of GDP). Turning points are now marked by the maximums and/or minimums of the trend deviation. GDP is regarded as the most comprehensive aggregated measure of the economic output of an economy.

For a four-phase division of the cycle, the four ideal-typical business cycle phases can be identified here by means of the sign of the trend deviation of GDP or its changes. In a "downturn" the trend deviation of real GDP is positive and the change of the trend deviation negative. In a "recession" both the trend deviation and the change of the trend deviation are negative. In an "upswing" the trend deviation is negative; however, the change of the trend deviation is already positive. In a "boom" the trend deviation of GDP is positive, and the same applies for change in the trend deviation.

The Federal Statistical Office arranges the four possible value pairs (trend deviation - change of the trend deviation) in a four-quadrant scheme, in which due to the axis arrangement, also a clockwise movement results (see Oltmanns 2009, 968). The trend deviation of GDP is represented on the abscissa, the change of the trend deviation on the ordinate. The upper left quadrant contains all paired values of the upswing phase, then there follow (clockwise) the quadrants for boom, downturn and recession. All the points above the abscissa signal the basic economic phase of expansion (with the partial phases: upswing and boom); all points below the abscissa signal the basic phase of contraction (with the partial phases downturn and recession, see fig. 3 ).

For the construction of an empirical GDP business cycle monitor - in the following concretely for the period 1971 to 2009 -the extraction of the cyclical component of GDP is necessary precondition. First, however, the quarterly GDP time series must be cleared off all non-cyclical components. For the elimination of the short-term seasonal fluctuations (including the elimination of calendar irregularities) the Census-X12-ARIMA procedure was selected. For the elimination of the long-term development path (trend) as well as the non-cyclical, short-term fluctuations, the Baxter-King filter was employed. 
Fig. 3

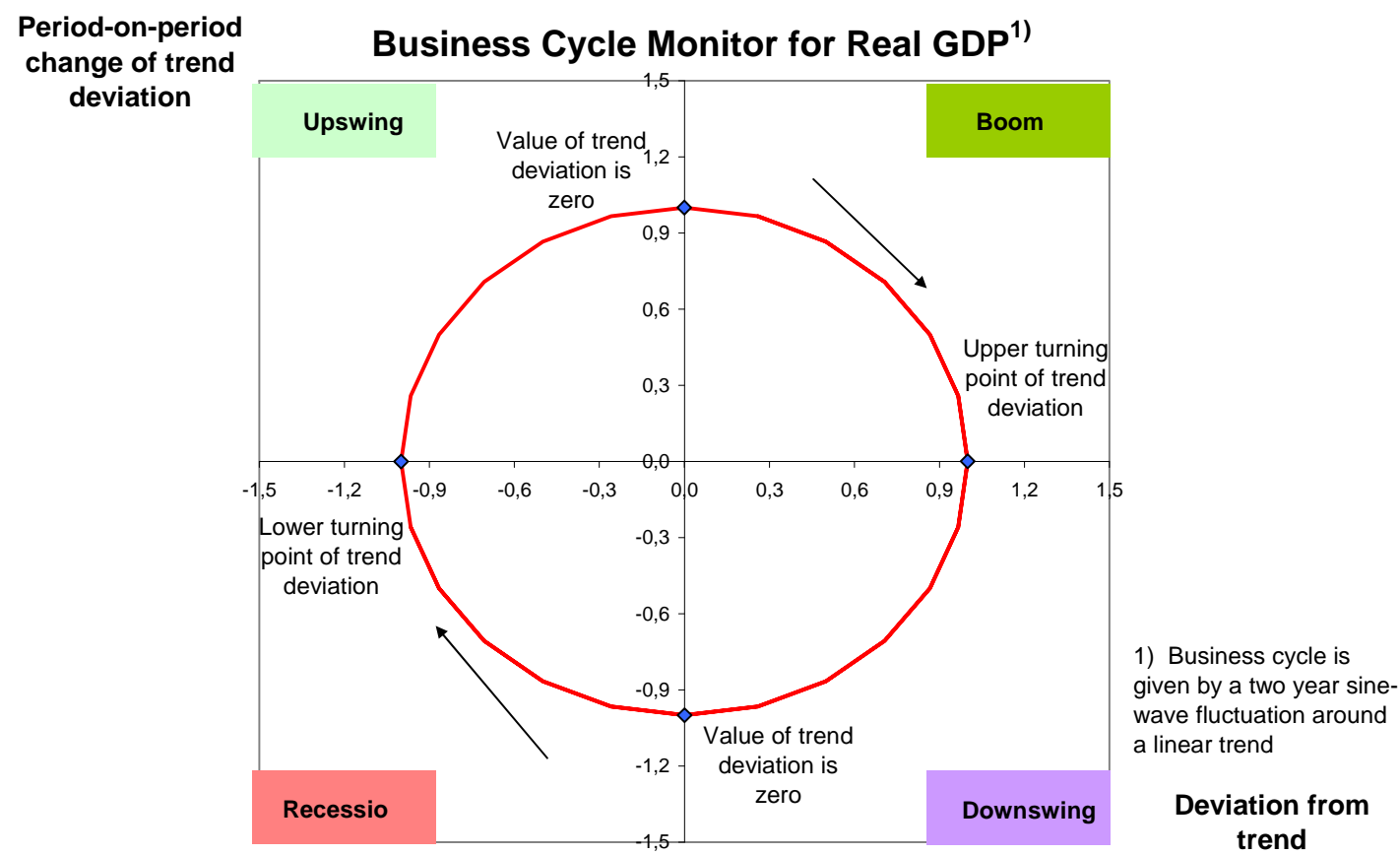

The Baxter-King-filter is a symmetrical filter which, in comparison to the Hodrick-Prescott filter, removes not only the low-frequency trend component but also the high-frequency irregularities contained in the time series. As a cycle the sum of all components of the time series with oscillations between 6 and 32 quarters (= of 1.5 to 8 years) was applied; the filter length amounts to 12 quarters ( $=3$ years). These settings correspond to the normal recommendations in the literature on the extraction of business cycles (see Mills 2003, p.91). ${ }^{1}$

To obtain a long time series, the lacking all-German GDP values for the period 1990 to 1971 were generated by linking the West German and all-German time series in 1991. Furthermore additional series values were predicted at the end of the GDP series in order to be able to apply a symmetrical filter here too. The "forecasts" were made with the help of autoregressive models (AR); the lag length was chosen automatically by means of the Akaike information criterion (AIC). Figure 4 shows the extracted cyclical component of real GDP and the turning points that

1 The Federal Statistical Office has chosen another approach for the extraction of the cyclical component of real GDP: First, the trend business-cycle component of GDP is estimated with the help of the Office's own time series analysis procedures BV4.1 (Berlin procedure, version 4.1). Then the trend of this series is determined with the help of the Hodrick-Prescott-filter with the parameter value typical for quarterly data of $\lambda=1600$. The deviations of the trend business-cycle component of the HP trend are then interpreted as business-cycle fluctuations. Via the parameter $\lambda$ the smoothness of the HP trend is controlled aprioristically. When $\lambda=0$ the resulting trend is the original series; with $\lambda$ up to "infinity" a linear trend (see Oltmanns 2009). 
were identified with the Bry-Boschan method (see Bry and Boschan 1971). This dating algorithm determines the cyclical turning points according to a sequential decision rule. ${ }^{1}$

Fig. 4

\section{Cyclical Component of Real GDP}

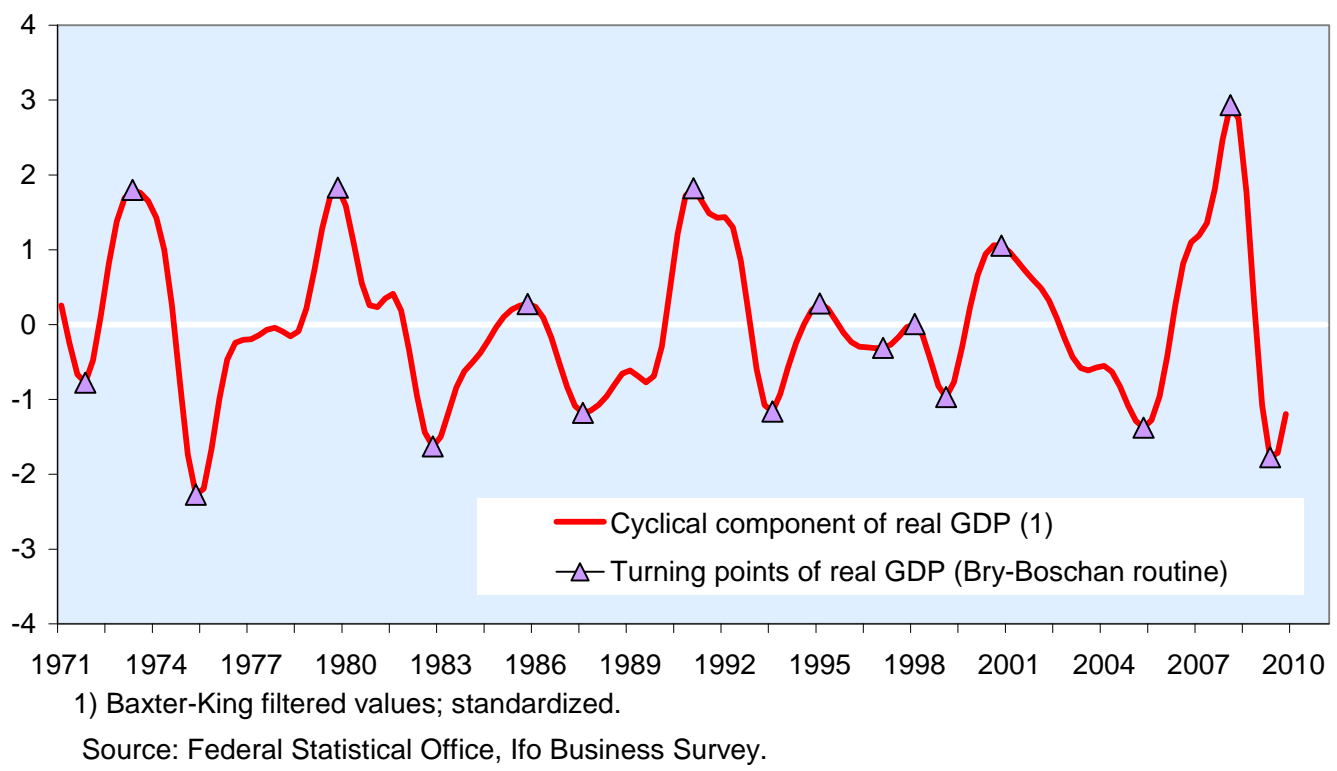

\section{Linear correlation with GDP}

In the Ifo Business Cycle Clock, the business situation of the surveyed companies are allocated to the business expectations at every point in time; the GDP-business cycle monitor shows the cyclical components of real GDP and its change over the previous quarter. In an initial step we discuss the linear correlation (Bravais-Pearson) between the series business situation and cyclical component of GDP as well as between the series business expectations and change in the cyclical GDO component. Since unlike the information on real GDP the data of the Ifo Business Survey is not in a quarterly frequency, the monthly survey results were combined into quarterly values for the business situation and the business expectations. Prior to this, all business survey time series were seasonally adjusted using the standard Ifo ASA II method in order to ensure the full compatibility with the regularly published business survey results.

1 The Baxter-King filtering and the turning point dating according to Bry-Boschan were carried out with the software tool BUSY (see Fiorentini and Planas 2003). 
Fig. 5

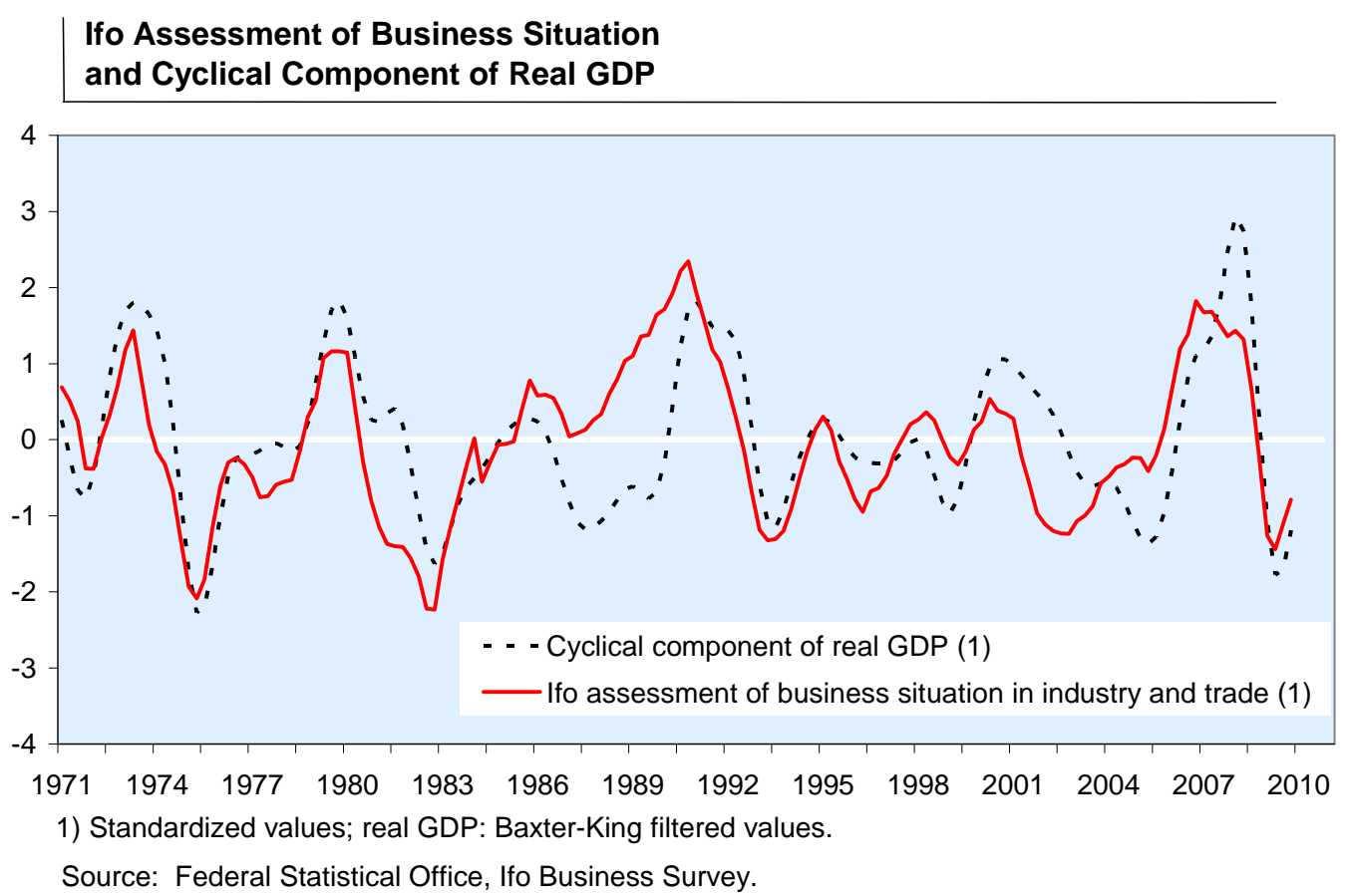

Figure 5 shows that the course of business situation and cyclical component of real GDP in the period 1971 to 2009 is quite similar; a narrow connection is manifest. Furthermore it is apparent that the business situation has a slight lead on the cyclical GDP component. The narrowest correlation between the business situation and the cyclical component of real GDP - measured in terms of the maximum of the correlation coefficient in the cross-correlogram - is seen when the business situation has a lead of one quarter; the correlation here amounts to 0.68 . The lead of the business situation can be explained by the fact that the profit situation, which plays an important role when firms assess their business situation, leads the cycle in general (see Abberger, Birnbrich and Seiler 2009, p.41). This is because the cost side of the firms is influenced by the labour market situation and by capacity utilization. Thus, in the late phase of an upswing, labour costs increase much faster than selling prices, which leads to a decline in profit margins. Conversely, in the late phase of a downturn, firms stabilize their profit situation via cost-cutting rationalisation measures. Moreover, in the beginning of an upswing the increase in labour costs is weak - if at all - due to the poor labour market and the mobilization of production reserves (see Zarnowitz 1992, 42). To explicitly measure the profit situation of firms by using leading indicators is very difficult, however. Zarnowitz $(1991,321)$ writes: "Important studies of business cycles ascribe a major role to profits; also, there is evidence of a strong tendency for total corporate profits to lead. But few concepts are more difficult to measure than profits in a true economic sense." 
Figure 6 shows the corresponding connection between the business expectations and the modification of the cyclical component of real GDP. Calculated along all the data points, the crosscorrelogram shows a coincidence between the two lines; the maximum correlation coefficient is achieved accordingly at a parallel course and amounts to 0.76 .

Fig. 6

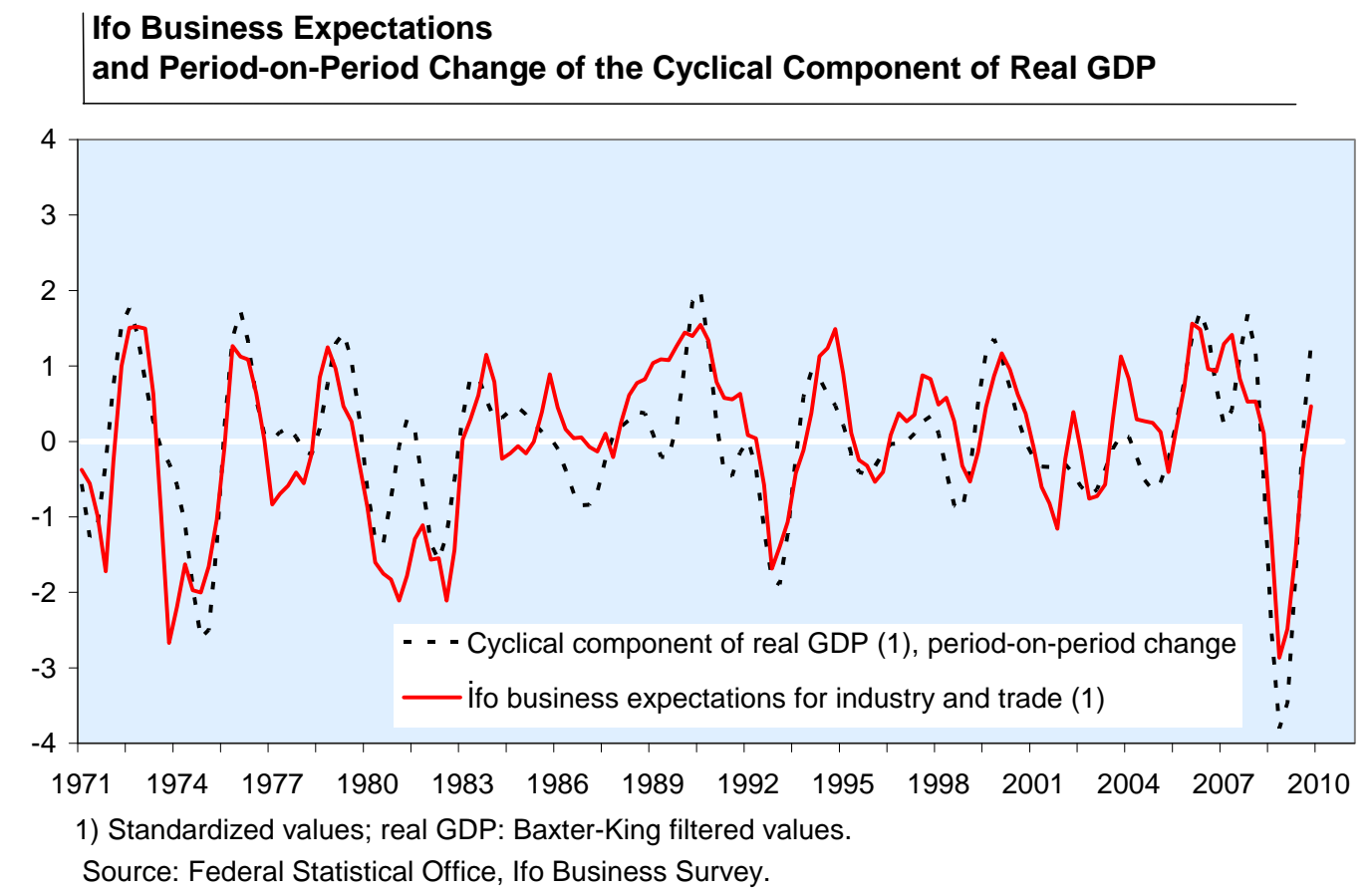

\section{Circular correlation with GDP: Orthognalization of Ifo input time series}

With the Ifo Business Cycle Clock, economic activity as a situation/expectations graph moves through the 4 quadrant scheme ideal-typically clockwise and in a circle. In contrast, the business cycle monitor shows whether and to what extent the cyclical component of real GDP is positive or negative and whether and to what extent the cyclical component increases or falls. Also in this system, ideal-typically a circular and clockwise movement of the business cycle results.

For the Ifo Business Cycle Clock, the assumption that economic activity move along a circular path through the four quadrant scheme is often not the case in practice, however. Even with ideal-typical sinusoidal curvatures of business situation and expectations, a completely round course of the clock results only if the two initial series stand orthogonally to each other. This characteristic is determined by the periodic time of the two functions and the phase shifts between them. If the initial series do not stand orthogonally to each other, an elliptic course of the 
clock results already in the model. ${ }^{1}$ This would be the case, for example, in the previously mentioned case of a two-yearn sinusoidal cycle if the (correctly anticipated) expectation indicator has only a lead of three months over the business situation. The ideal-typical circular rotation of the clock is thereby bent to a movement along the main diagonals that connect the boom quadrant with the recession quadrant. In these cases, the business situation can already improve (or worsen), although the business expectations are still negative (or positive).

Empirical observations in the boom or recession quadrants are thus more frequent than observations in the upswing or downturn quadrants. The distortion of the Ifo Business Cycle Clock by the violation of the orthogonality condition can however be eliminated by a purely data controlled transformation of business situation and business expectations. The mathematical instrument for this is the principal component analysis. This is based in turn on the so-called spectral decomposition or Jordan decomposition. Accordingly a symmetrical A matrix $(p \times p)$ can be written as

$$
A=\Gamma \Lambda \Gamma^{T}
$$

with $\Lambda$ being a diagonal matrix of the eigenvalues of $\mathrm{A}$, and $\Gamma$ an orthogonal matrix whose columns are formed by the standardized eigenvectors. Since the business cycle clock is twodimensional, $\mathrm{p}=2$ applies here, and there are two eigenvectors and two corresponding eigenvalues. $\lambda_{1}$ and $\lambda_{2}$. are the eigenvalues of $A$. If the clock followed an exact circle, $\lambda_{1}=\lambda_{2}$. would result. If we have an ellipse, different eigenvalues result. If $\lambda_{1}>\lambda_{2}$. and if $\gamma_{1}$ and $\gamma_{2}$ are the corresponding eigenvectors, then vector $\gamma_{1}$ indicates the direction of the greatest extension of the ellipse (see Mardia, Kent and Bibby 2000, 484). Thus, the direction sought for in step 1 of the procedure has been found. The direction for the second straight line is now also present and is determined by $\gamma_{2}$. Matrix $\Gamma$ thus brings about the rotation described in step 2. In practical terms, this means the following: let $\mathrm{X}$ be a $(2 \times T)$ matrix that contains $\mathrm{T}$ observations for the two variables business situation and business expectations. It has the expectations value vector $\mu$ and the variance-covariance matrix $\Sigma$. Step 1 of the procedure consists in the spectral decomposition of the variance-covariance matrix $\Sigma$. Step 2 is thus the transformation

$$
X \rightarrow Y=\Gamma^{T}(X-\mu)
$$

With $\Gamma$ the rotation in step 4 is of course also determined, which reverses the turning in step 2. What remains is the standardization in step 3. Here we can make use of the fact that the determined eigenvalues are equal to the variances of $Y$. It is the case that $\operatorname{Var}\left(\mathrm{y}_{1}\right)=\lambda_{1}$ and $\operatorname{Var}\left(\mathrm{y}_{2}\right)=\lambda_{2}$

1 Two functions $f(x), g(x)$ are orthogonal in the interval $[a, b]$, when the product $f(x) g(x)$ is a function with the integral nought in the range $[\mathrm{a}, \mathrm{b}]$. 
(see Mardia, Kent and Bibby 2000, 215). With $\Phi=\operatorname{diag}\left(\lambda_{1}{ }^{1 / 2}, \lambda_{2}{ }^{1 / 2}\right)$ it follows that the entire transformation that is described above in steps 1 to 4 can be represented by

$$
X \rightarrow Z=\left(\Gamma^{T}\right)^{-1} \Phi^{-1} \Gamma^{T}(X-\mu)
$$

Since $\Gamma$ is an orthogonal matrix, the transformation can be simplified to

$$
X \rightarrow Z=\Gamma \Phi^{-1} \Gamma^{T}(X-\mu)
$$

whereby $\Phi^{-1}=\operatorname{diag}\left(1 / \lambda_{1}{ }^{1 / 2}, 1 / \lambda_{2}{ }^{1 / 2}\right.$. This demonstrated transformation can be understood as an expanded standardization. In addition to the usual standardization of averages and variance, the covariance is additionally set to nought. For the following calculations for the circular correlation, the Ifo Business Cycle Clock has been orthogonalized in this form. For the GDP business cycle monitor, this transformation has not been carried out because the cyclical component of GDP cannot rise (fall) as long as the negative (positive) trend deviation has not reached its local minimum (maximum), so that here a round, although not exactly circular course, is mathematically predetermined.

\section{Circular correlation with the GDP: Visual test}

By means of the cyclical component of real GDP, a total eight complete business cycles can be identified in period under investigation - 1971 to 2009 (see Fig. 4); the average cycle duration measured by the space of time between two turning points that follow on each other - is approximately $4 \frac{1}{2}$ years. For the following visual test of the two monitoring systems with regard to agreement as to the basic cyclical movements, the period under investigation was divided into seven 5-year sections (beginning with 1971 to 1975) as well as a 4-year section that contains the remaining years 2005 to 2009. In total, 156 quarters are thus considered.

In Figure 7, the interplay of Ifo Business Cycle Clock for industry and trade with the business cycle monitor for real GDP is present in a four-part graph for 1971 to 1990 . This period contains, first of all, the serious recession in the wake of the first oil crisis 1973/74, from which the western German economy first began to free itself again in 1975 (upper left graph, Fig. 7). The upper right graph in Fig 7 shows both upswing years 1978/79, after that economic activity measured by the worsening expectations and the declining cyclical GDP components - 
Fig. 7

Ifo Business Cycle Clock for Industry and Trade and Business Cycle Monitor for Real GDP ${ }^{\text {a) }}$

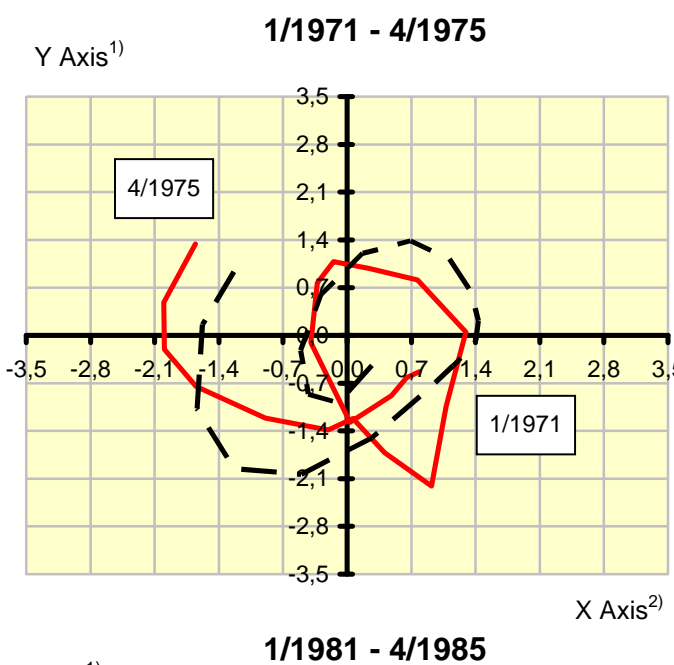

Y Axis $^{1)}$

$1 / 1976-4 / 1980$
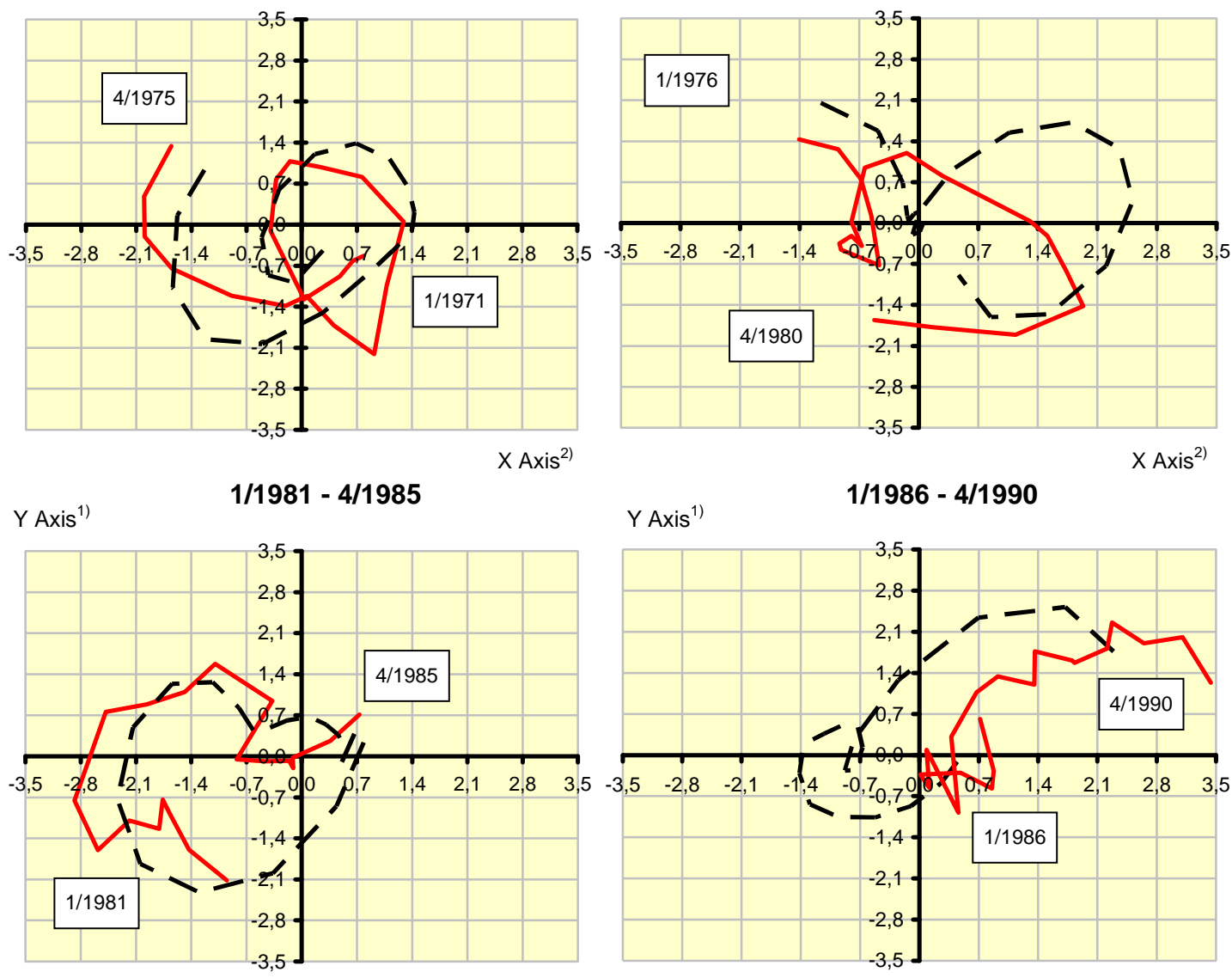

$\mathrm{Axis}^{2)}$

X Axis $^{2)}$

a) Ifo business cycle clock: saisonally adjusted results using ASAll; orthogonalized values; business cycle monitor for real GDP (dashed line): saisonally and calender adjusted results using Census X12-ARIMA; Baxter-King filtered. All values are scale-standardized using the transformation $Z$ / $\mathrm{S}$, where $\mathrm{Z}$ is the original value and $S$ is the standard deviation.of the sample.

1) Y Axis: Ifo business cycle clock: business expectations for the next six months (balances); business cycle monitor for real GDP: period-on-period change of cyclical component.

2) X Axis: Ifo business cycle clock: business situation (balances); business cycle monitor for real GDP:

cyclical component.

Source: Federal Statistical Office, Ifo Business Survey.

deteriorated rapidly in connection with the second oil crisis. The lower left graph contains conditional stagflation year 1981 caused by the oil crisis (growth rate of real GDP: $0.5 \%$; inflation rate: 6.3\%). Not until the conservative/liberal coalition assumed power in autumn 1982 was there an improvement in economic activity; the introduction of an investment grant started up the investment engine. In spring 1984, however, a 7-week strike in the metal industry over the introduction of the 35-hour week led to high losses in production that caused firms business 
expectations to collapse and which also can be seen in the cyclical component of GDP. The lower-right graph ends with the western German unification boom of 1989/90, whereby business activity had already been positively stimulated before by gradual tax reductions and lower oil prices. The graphs of the Ifo Business Cycle Clock and the GDP business cycle monitor both remain at the end of 1990 in the northeast boom quadrant.

Figure 8 shows the interplay between the Ifo Business Cycle Clock for industry and trade with the business cycle monitor for real GDP in reunited Germany since 1991. The upper left graph in Figure 8 shows firstly the end of the unification boom: beginning with the first quarter of 1991 the business situation and cyclical GDP component fall as order stock decrease strongly. The business expectations, however, remained unchanged to a large extent until 1992; many companies presumably anticipated a quick improvement of US economic activity. The economic downturn intensified in the second half of 1992, fed by the flaring up of the solidarity pact discussion with regard to drastic increases in taxes and fiscal charges and by turbulence in the European monetary system (EMS). In the second half of 1993 an economic recovery began that intensified in 1994, boosted by strongly rising exports and much improved profit outlooks. In 1995 the business expectations worsened considerably and also the cyclical GDP component declined. The upper right graph in Figure 8 begins with the new upswing of 1996/97: key interest rates had fallen to historical lows and moderate wage settlements had improved firms' profit situation. In the course of 1998 the economic crisis in eastern Asia, the difficulties in Russia and the weakening in Latin America became apparent. The export economy and also the cyclical component of real GDP reached their lows in the first quarter of 1999. After that the buoyancy forces strengthened, culminating in the New Economy boom of 2000.

The lower left graph in Figure 8 reflects the overall weak and unstable development of economic activity in the years 2001 to 2005; unlike all the other examined periods, both the Ifo Business Cycle Clock and the GDP Monitor show no unambiguous cyclical pattern. In 2001, contrary to expectations, economic activity experienced a "hard landing", intensified by the terror attacks of 11 September. In the following year the increasing tension in the Iraq conflict led to insecurity; additional factors were the rise in crude oil prices as well as the strong declines on the financial markets. In 2003 the Iraq conflict escalated into an open military confrontation. The euro also increased in value strongly against the US dollar, which had an affect on exports. In the domestic economy, consumer sentiment worsened in connection with the Agenda 2010 reforms. The downturn in the business cycle that occurred with a negative business situation 
Fig. 8

Ifo Business Cycle Clock for Industry and Trade and Business Cycle Monitor for Real GDP ${ }^{\text {a) }}$

Y Axis $^{1)}$

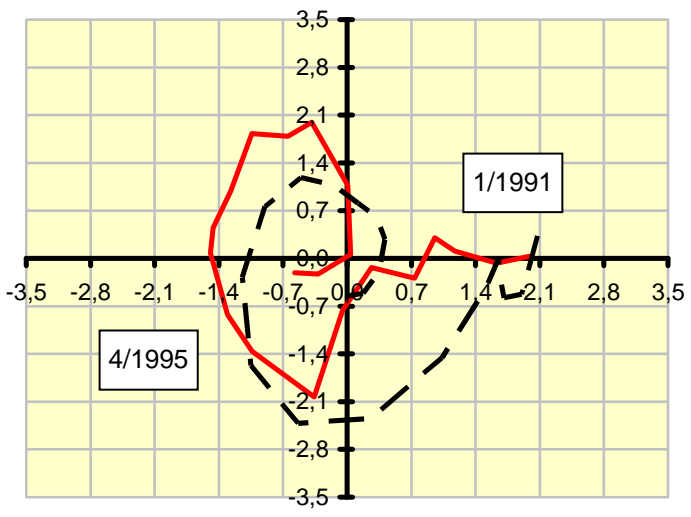

$X$ Axis $^{2)}$

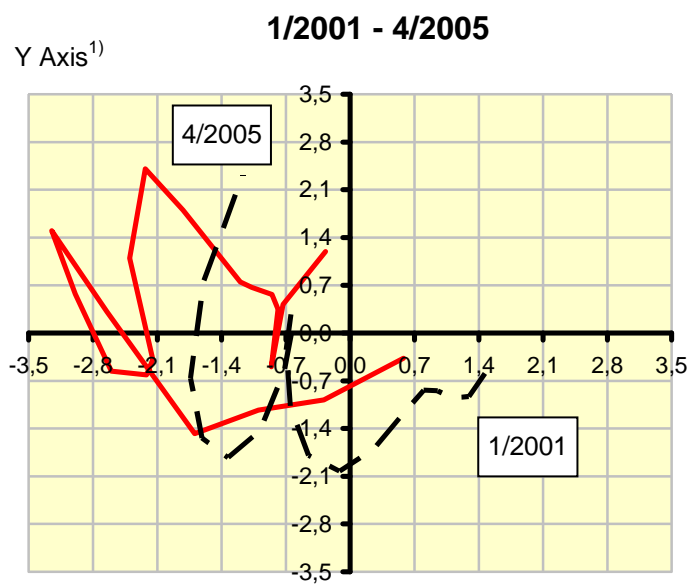

$\mathrm{Axis}^{2)}$
Y Axis $^{1)}$

$1 / 1996-4 / 2000$

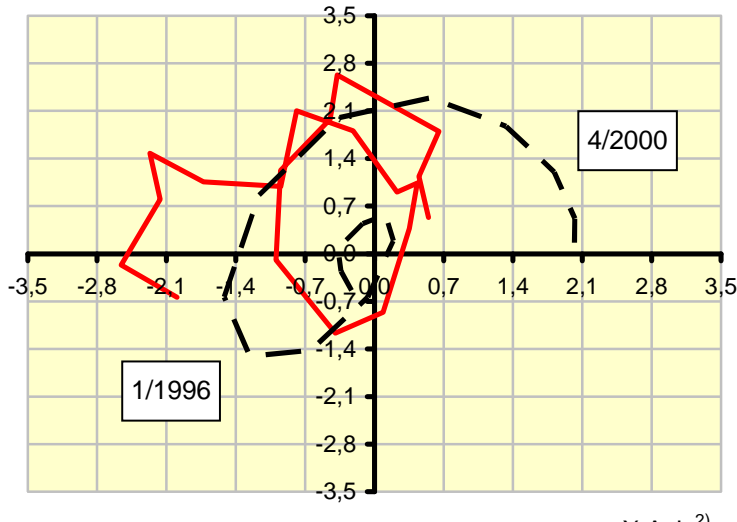

$1 / 2006-4 / 2009$

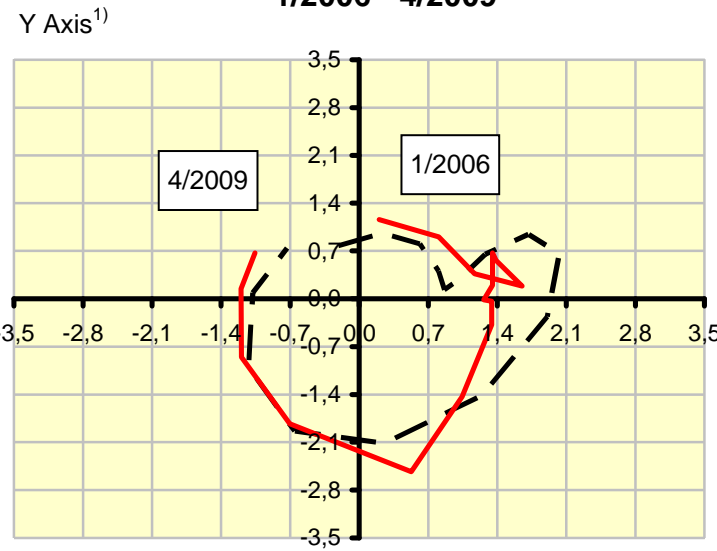

$X$ Axis $^{2)}$

a) Ifo business cycle clock: saisonally adjusted results using ASAll; orthogonalized values; business cycle monitor for real GDP (dashed line): saisonally and calender adjusted results using Census X12-ARIMA; Baxter-King filtered. All values are scale-standardized using the transformation $Z$ / S, where $Z$ is the original value and $\mathrm{S}$ is the standard deviation. of the sample.

1) Y Axis: Ifo business cycle clock: business expectations for the next six months (balances); business cycle monitor for real GDP: period-on-period change of cyclical component.

2) X Axis: Ifo business cycle clock: business situation (balances); business cycle monitor for real GDP:

cyclical component.

Source: Federal Statistical Office, Ifo Business Survey.

and strong fluctuations in the business expectations of the surveyed firms did not end until the second quarter of 2005 when business expectations brightened and also the cyclical component of GDP began to rise. The growth engine was once again foreign demand that unfolded not least because of dynamic growth in the world economy and the once again more favourable eurodollar exchange rate. 
The lower right graph in Figure 8 shows the cyclical development up to the fourth quarter of 2009. In 2006 upswing continued, with exports being the most important support amidst the continuingly favourable international environment. In 2007 the upswing went on although VAT had been increased substantially to help consolidate the government budget. In the first quarter of 2008, the upper cyclical turning point was reached, thereafter the economy cooled off in the wake of the recessions in the US and Japan. Finally in autumn 2008 the German economy also went into the recession. With the collapse of the US investment bank Lehmann Brothers, the financial crisis reached a climax worldwide. The lower economic turning point - measured by the cyclical component of real GDP - was reached in the second quarter of 2009; since then economic activity stabilised at a low level. Both the Ifo Business Cycle Clock and the GDP business cycle monitor point upwards again; since the third quarter of 2009 both graphs are in the upswing quadrant. Summing up, the correlation of the two monitoring systems is quite substantial also in this period.

\section{Circular correlation with GDP: Statistical results}

The two input series employed for the Ifo Business Cycle Clock and the corresponding time series of the GDP Monitor display a high degree of correlation. With the help of a circular correlation analysis, the similarity in the movement pattern of the two systems can be quantified. This analysis technique examines the connection between circular random variables, or between a circular random variable and linear random variables. A random variable is deemed to be circular if its two-dimensional direction can be measured as angles in relation to a chosen "nought direction". In order to examine the movement patterns of the two 4-quadrant schemes, circular variable are defined for both. ${ }^{1}$ To do this, the data sections presented in Figure 7 and 8 are individually standardised and for every data point of the movement line of the angle between the abscissa and the vector from the beginning to the respective data point is calculated. Since both the Clock and the Monitor are treated in this manner, two data sets result, each with circular variables. By means of the described transformation in circular variables, in the correlation analysis the focus is exclusively on the direction of the motion of the two systems. The concrete location of the points does enter into the analysis.

1 The Business Cycle Clock and the Business Cycle Monitor cannot be examined with the usual correlation analysis of Bravais-Person since it is not a matter of an observation on a time axis but a rotating representation. For example, the number pair 0.05 and 11.55 , interpreted as numbers, lie quite far from each other. Interpreted as times on a clock, they are however very close together (nearer for example than 11.55 and 11.15). 
Concretely, we examine the linear connection between two circular random variables $\Theta$ and $\Phi$. Let $p_{1}=\left(\theta_{1}, \phi_{1}\right), \ldots, p_{n}=\left(\theta_{n}, \phi_{n}\right)$ be a coincidence random sample of the circular random variables $\mathrm{P}=(\Theta, \Phi)$. Then a $\mathrm{T}$-linear relationship exists between the variables if

$$
\left.\Phi=\Theta+\theta_{0} \text { (Modulo } 360^{\circ}\right)
$$

or

$$
\Phi=-\Theta+\theta_{0}\left(\text { Modulo } 360^{\circ}\right)
$$

with $\theta_{0}$ as a constant angle. The strength of such a linear connection can be measured by

$$
\hat{\rho}_{T}=\frac{\sum_{1 \leq i<j \leq n} \sin \left(\theta_{i}-\theta_{j}\right) \sin \left(\phi_{i}-\phi_{j}\right)}{\left[\sum_{1 \leq i<j \leq n} \sin ^{2}\left(\theta_{i}-\theta_{j}\right) \sum_{1 \leq i<j \leq n} \sin ^{2}\left(\phi_{i}-\phi_{j}\right)\right]^{1 / 2}}
$$

Jammalamadaka and SenGupta (2001) in addition present a test for this type of correlation. The null hypothesis on the presence of no T-linear relationship is accordingly rejected when $\hat{\rho}_{T}$ deviates too far from zero. The p-values for this test are also indicated in the following.

Table 1 shows the amounts and the p-values for the circular correlation. The impressions from the visual comparison the 4-quadrant depictions are clearly confirmed. The null hypotheses on the presence of no T-linear relationship are rejected for the significance level 0.05 for all time windows except for one. The hypothesis is (barely) not rejected for the period $1 / 2001$ to $4 / 2005$, which was already identified as crucial. Nevertheless, here too the correlation with a value of 0.44 is considerable. On the whole, the calculations for the circular correlation confirm that the movement patterns of the Ifo Business Cycle Clock and the Business Cycle Monitor show great similarity.

In a further step we analyse how clear the signals are of the survey-based Ifo Business Cycle Clock in the two basic phases expansion/contraction - measured in terms of the results of the GDP Monitor. The Business Cycle Monitor shows the basic phase expansion (contraction), when the data points in the two quadrants are above (below) the abscissa. This is always the case when the change of the cyclical component of real GDP is positive (or negative). On the other hand, the Ifo Business Cycle Clock signals the basic phase expansion (contraction), when the transformed expectations of the firms are on balance positive (or negative). Also in this monitoring system, the data points lie in the two quadrants (below) the abscissa. 
Tab. 1

\section{Ifo Business Cycle Clock for Industry and Trade and Business Cycle Monitor for Real GDP ${ }^{1)}$}

\begin{tabular}{|l|c|c|}
\hline Period & Correlation coefficient & $p$-value \\
\hline $1 / 1971-4 / 1975$ & 0.68 & 0.0070 \\
\hline $1 / 1976-4 / 1980$ & 0.86 & 0.0019 \\
\hline $1 / 1981-4 / 1985$ & 0.71 & 0.0045 \\
\hline $1 / 1985-4 / 1990$ & 0.57 & 0.0108 \\
\hline $1 / 1991-4 / 1995$ & 0.89 & 0.0007 \\
\hline $1 / 1996-4 / 2000$ & 0.43 & 0.0310 \\
\hline $1 / 2001-4 / 2005$ & 0.44 & 0.0653 \\
\hline $1 / 2006-4 / 2009$ & 0.85 & 0.0084 \\
\hline 1$)$ Standardized series.
\end{tabular}

In the period under investigation, there are a total of 156 observations; of these 81 observations fall in the categories upswing or boom according to the classification of the GDP Monitor; the Ifo Business Cycle Clock is able to identify 64 cases (see Tab. 2). Conversely, 75 observations fall in the categories downturn or recession. The Ifo Business Cycle Clock accurately identifies 55 cases. However in 37 cases there is a false classification. Thus, in 20 cases the Ifo Business Clock signals a downturn or recession, which according to the GDP Monitor would have to be classified as upswing or boom. The error rate is thus $24 \%$. This shows that the Ifo Business Cycle Clock is less suitable for an exact separation of the two basic phases expansion/contraction. Even though the movement patterns of the clock are reasonable, for an exact dating analysis, however, instruments especially optimised for this purpose should be used. ${ }^{1}$

Tab. 2

\section{Cross Table}

\begin{tabular}{|c|c|c|c|c|}
\hline & \multicolumn{2}{|c|}{$\begin{array}{l}\text { Change of the } \\
\text { cyclical component of real GDP }\end{array}$} & \multirow[t]{2}{*}{ Total } \\
\hline & & is positive $^{1)}$ & is negative $^{2)}$ & \\
\hline $\begin{array}{l}\text { Balance value } \\
\text { of the current }\end{array}$ & is positive ${ }^{3)}$ & 64 & 20 & 84 \\
\hline business situation ${ }^{5)}$ & is negative $^{4)}$ & 17 & 55 & 72 \\
\hline & Total & 81 & 75 & 156 \\
\hline $\begin{array}{l}\text { 1) Business Cycle Monito } \\
\text { 2) Business Cycle Monito } \\
\text { 1) Ifo Business Cycle Cloc } \\
\text { 2) Ifo Business Cycle Cloc } \\
\text { 5) Industry and trade, orth }\end{array}$ & $\begin{array}{l}\text { eal GDP is in } \\
\text { eal GDP is in } \\
n \text { upswing qu } \\
n \text { downswing } \\
\text { alized values. }\end{array}$ & $\begin{array}{l}\text { ing quadrant } \\
\text { swing quadra } \\
\text { t or in boom q } \\
\text { ant or in rece }\end{array}$ & $\begin{array}{l}\text { om quadrant. } \\
\text { recession qua } \\
\text { t. } \\
\text { uadrant. }\end{array}$ & \\
\hline
\end{tabular}

1 The Ifo Business Cycle Traffic Light, based on a Markov regime-change approach, is particularly well suited for dating the basic phases of expansion or contraction (see Abberger and Nierhaus 2010b). 


\section{Linear-circular correlation with the monthly gross domestic product: Disaggregation after Chow \& Lin}

In order to have to manipulate as little as possible the quarterly input series from the official statistics, the comparison of the Ifo Business Cycle Clock with the GDP Business Cycle Monitor presupposes the use of quarteralised business cycle survey data. If, however, we focus only on the cyclical connection between real GDP and the Ifo Business Cycle Clock (linear-circular correlation), a limitation to quarterly data is not longer absolutely necessary. The use of original, i.e. monthly business cycle data, presupposes, however, that the quarterly results supplied by the Federal Statistical Office are converted into consistent monthly values for real GDP (temporal disaggregation). The well established Chow \& Lin method is used here for the generation of monthly GDP values (see Chow and Lin 1971).

In concrete terms, with the help of quarterly data, the estimated regression relationship between real GDP and a higher frequency business cycle indicator is converted to months. This approach is based on the hypothesis that the higher frequency (in this case monthly) indicator series provides a correct depiction of real GDP. In order to exclude a possible distortion of the temporal disaggregation by seasonal effects, here too the seasonally and calendar adjusted quarterly results of GDP were employed. As a monthly indicator series for the temporal dissection of quarterly GDP, firstly the production index for the producing trade was used, which in addition to manufacturing also includes construction and the energy and water supply. Secondly, the index of real retail sales was employed. ${ }^{1}$ These economic sectors, which correspond in their sum approximately to the sector industry and trade in delimitation of the Ifo Institute, account for about a third of domestic GDP. These two indices were compacted for the period 1994 to 2009 with the help of the value-added shares to form a comprehensive monthly indicator "industry and trade" (see Fig. 9).

In order to serve as a reference for a temporal disaggregation of real GDP, this indicator must satisfy two criteria. On the one hand, it should be co-integrated with the real GDP, on a quarterly basis. On the other hand, the cyclical component of the index should agree as much as possible with the cyclical component of real GDP.

The approach chosen here is based on a regression between the quarterly time series "production index in industry and trade" and GDP. These time series, however, are not stationary so that a regression of the level variables is only reasonable from statistical viewpoint if the variables in the model are co-integrated. For the regression used here, test procedures developed by Johansen for the examination of co-integration were used (Johansen's trade test). The model underly-

1 On the other hand the real sales in the wholesale are not considered, because for these no official seasonally and calendar adjusted data according to Census-X12-ARIMA is available. 
ing the test was specified so that it contains an unrestricted "drift term". This test rejects the null hypothesis for the significance level 0.01 , that no co-integration relationship exists between the two variables. In purely visual terms, in Figure 9 one sees a similar trend behaviour of the two variables, whereby also intermittently prominent differences consist in the development path of the variables. On the whole, however, the regression between the two level variables appears to be justified.

Fig. 9

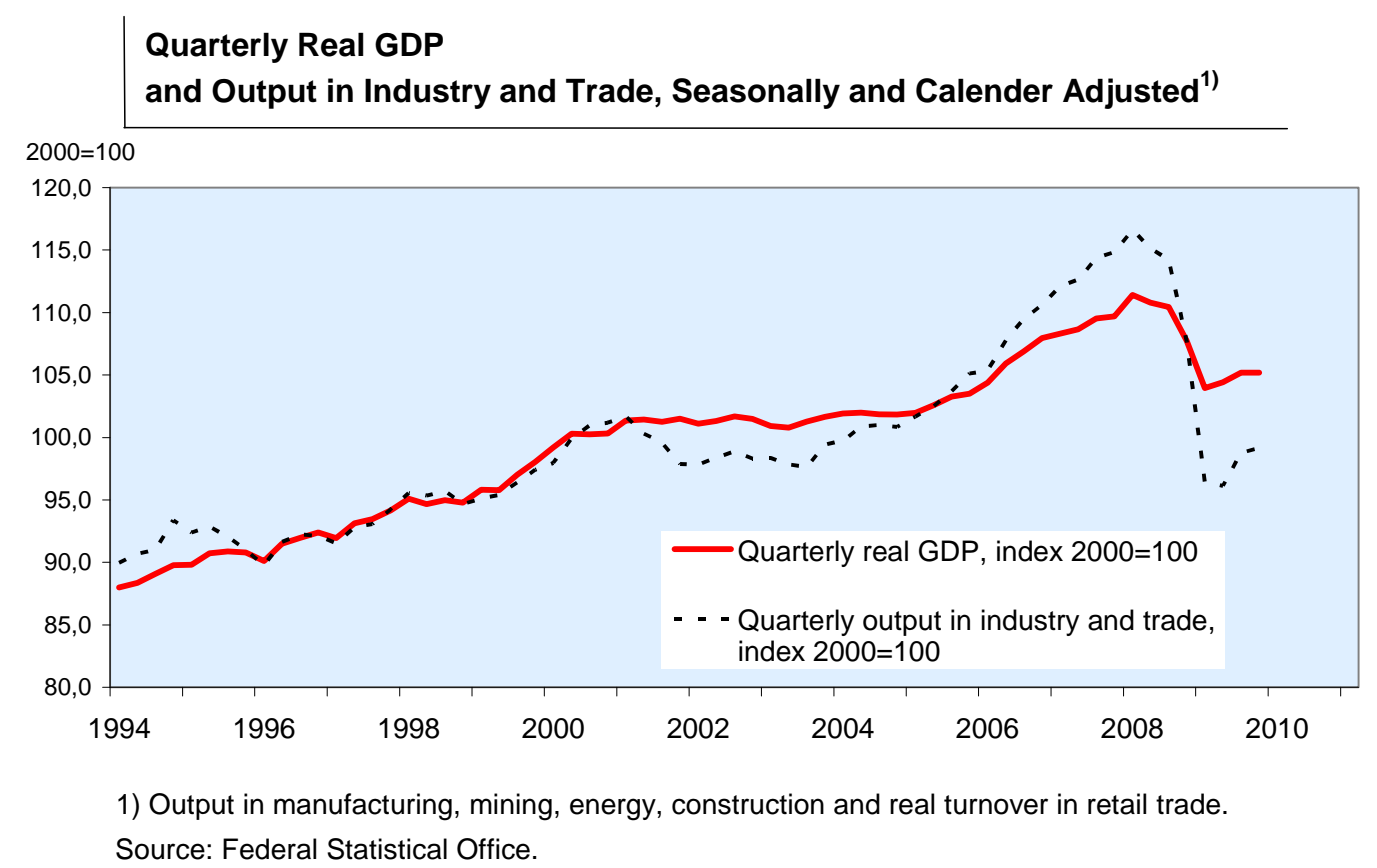

A further criterion for the suitability of the employed monthly reference indicator industry and trade is whether its cyclical component agrees well with the cyclical component of the temporally disaggregated GDP. ${ }^{1}$ For extracting the cyclical components, the Baxter-King filter was used once again. Figure 10 shows the great visual agreement between the two series; the maximum value of the cross correlation function is reached in the case of coincidence and amounts to 0.92 .

1 The disaggregation is done with the help of the software tool ECOTRIM (see Barcellan and Buono 2002). 
Fig. 10

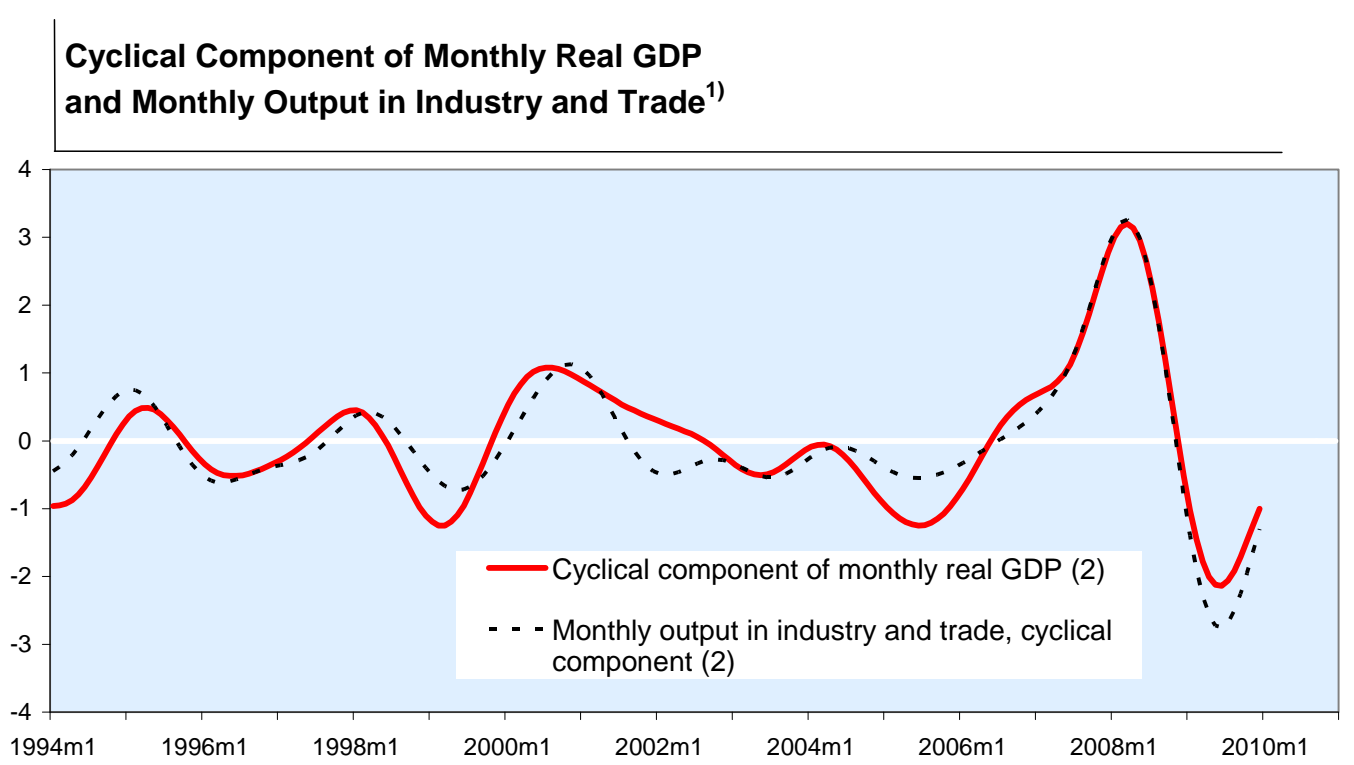

1) Output in manufacturing, mining, energy, construction and real turnover in retail trade. 2) Standardized values, Baxter-King filtered.

Source: Federal Statistical Office.

\section{Linear-circular correlation with monthly GDP: statistical results}

The cyclical component of monthly GDP is a "common" linear variable, whereas the Ifo Business Cycle Clock is a circular variable. For the following analysis a measurement is thus needed for a linear-circular correlation, that is a correlation between a linear and a circular variable. A suitable measurement of the correlation between a linear variable and a circular variable is the multiple correlation between the linear variable $X$ and the components $(\operatorname{cosine} \alpha, \sin \alpha)$ of the circular variables $\alpha$ (see Mardia 1976 as well as Johnson and Wehrly 1977). Such a measurement is

$$
\begin{aligned}
& r^{2}=\frac{r_{x c}^{2}+r_{x s}^{2}-2 r_{x c} r_{x s} r_{c s}}{1-r_{c s}^{2}}, \text { with } \\
& r_{x c}=\operatorname{correlation}(x, \cos \alpha) \\
& r_{x s}=\operatorname{correlation}(x, \sin \alpha) \\
& r_{c s}=\operatorname{correlation}(\cos \alpha, \sin \alpha) .
\end{aligned}
$$

For the Ifo Business Cycle Clock variable $\alpha$ is computed as

$$
\alpha_{t}=\arctan \left\{\frac{\text { net balances } B E_{t}}{\text { net balances } B S_{t}}\right\} \text {, }
$$


whereby the two time series of the net balances are both adjusted for mean values. The computed correlation between the Clock and the cyclical component of GDP amounts to 0.69 and is thus clearly positive. The correlation between the Clock and production in industry and trade is even greater, displaying a value of 0.71 . Thus, also for these results based on monthly input series, it is clear that the Ifo Business Cycle Clock displays and reflects the movement of the German economy very well.

\section{Conclusion}

For many years, the Ifo Business Climate has been the most important leading indicator for the economic developments in Germany. Since the 1990s the cyclical connection between the two components of the business climate is displayed by the Ifo Institute as a 4-quadrant business cycle scheme (Ifo Business Cycle Clock). In the meantime, similar monitoring systems have been established, such as the Monitor for Real GDP by the German Federal Statistical Office. These monitoring systems focus on the cyclical component of an indicator or on their changes. For the input series of the Ifo Business Cycle Clock and the GDP Monitor constructed for Germany with the help of the Baxter-King filter, a close correlation exists already in the time component. A visual examination of both 4-quadrant schemes shows a largely consistent match of over the past 40 years. The impressions from the optical comparison are clearly confirmed by a statistical test. On the whole, the calculations show that the movement patterns of the Ifo of Business Cycle Clock and the GDP Monitor display great similarity. With the measure of the linear-circular correlation, the interplay of the direction of motion of The Business Cycle Clock with the cyclical components of real GDP is analyses on a monthly basis. With the help of the Chow \& Lin procedure, the official quarterly GDP results were converted into monthly values for the examination.

In comparison to the GDP Monitor, the Ifo Business Cycle Clock shows the cyclical development without the need for a previous trend adjustment of the input series. This can be a considerable advantage, since in practice the extraction of the cyclical component with the aid of statistical filter procedures is not unproblematic. The course of economic activity and the cyclical turning points are based on the filter that is used - a connection that Canova pointed out at in a widely read study of 1998. A further problem is that the filtered developments at the current edge of the time series, which is very important for forecasts, are very unstable and substantial revisions may occur, when new data are available. Thus, the evaluation of the filtered time series is very unsure at the edge of the observation area. New data can change the picture drawn through the filter clearly (see emperor and Maravall 2001). In the case of the survey-based Ifo Business Cycle Clock, this problem does not occur, since here there are no data revisions, no filtering and the additional orthogonalisation is carried out for all data points, so that new values do not have an appreciable influence on the result. 
All in all, the Ifo Business Cycle Clock is capable of representing the development of economic activity in the overall economy and the associated economic dynamics only on the basis of company assessments and appraisals. For business cycle analysis it has the advantage that it is available at an early point in time, is not subject to revisions and gives clear signals without many disturbances. In this way it possess the features that are important for business cycle analysis (see Moore and Shiskin 1967). However, the Ifo Business Cycle Clock is less suitable for a sharp distinction of the individual business cycle phases from each other. For an exact cycle classification, one should use instruments that have been optimised for this purpose. On the other hand, the strength of the Ifo Business Cycle Clock is its very good visualization of the economic dynamics.

\section{References}

Abberger, K. (2005), "Another Look at the Ifo Business Cycle Clock", Journal of Business Cycle Measurement and Analysis, 2(3), 431-43.

Abberger, K. and K. Wohlrabe (2006), "Einige Prognoseeigenschaften des ifo Geschäftsklimas - Ein Überblick über die neuere wissenschaftliche Literatur", ifo Schnelldienst 59(22) 19-26.

Abberger, K. and W. Nierhaus (2007), "Das ifo Geschäftsklima: Ein zuverlässiger Frühindikator der Konjunktur”, ifo Schnelldienst 60(5), 25-30.

Abberger, K. and W. Nierhaus (2008a), "How to Define a Recession?", CESifo Forum 9(4), 2008, 74-46.

Abberger, K. and W. Nierhaus (2008b), "Die ifo Konjunkturuhr: Ein Präzisionswerk zur Analyse der Wirtschaft”, ifo Schnelldienst 61(23), 16-24.

Abberger, K. and W. Nierhaus (2009), "Months for Cyclical Dominance und ifo Geschäftsklima”, ifo Schnelldienst 62(7), 11-19.

Abberger, K., and M. Birnbrich, C. Seiler (2009), "Der 'Test des Tests' im Handel - Eine Metaumfrage zum ifo Konjunkturtest”, ifo Schnelldienst 62(21), 34-41.

Abberger, K. and W. Nierhaus (2010a), "Die ifo Konjunkturuhr: Zirkulare Korrelation mit dem Bruttoinlandsprodukt", ifo Schnelldienst 63(5), 32-42.

Abberger, K. and W. Nierhaus (2010b), "Markov Switching and the Ifo Business Climate: the Ifo Business Cycle Traffic Lights", Journal of Business Cycle Measurement and Analysis, in press.

Barcellan, R. and D. Buono, "Temporal Disaggregation Techniques", ECOTRIM Interface (Version 1.01), User Manual, Eurostat, 2002.

Bry, G. and C. Boschan (1971), "Cyclical Analysis of Time Series: Selected Procedures and Computer Programs", NBER Technical Paper, 20, Cambridge (Mass.).

Canova, F. (1998), "Detrending and business cycle facts", Journal of Monetary Economics, 41, $475-512$. 
Chow, G. C. and A Lin (1971), "Best linear unbiased interpolation, distribution and exploration of time series by related series", The Review of Economics and Statistics, 53(4), 372-75.

Eurostat (2010), The European Business Cycle Clock, http://epp.eurostat.ec.europa.eu/cache/BCC/explanation_en.htm

Fiorentini, G. and C. Planas (2003), Busy Program, Joint Research Center of Europaen Commission, Ispra, Italy.

Gayer, C (2010) "Report: The Economic Climate Tracer - A tool to visualise the cyclical stance of the economy using survey data", http://www.oecd.org/dataoecd/12/47/39578745.pdf.

Jammalamadaka, S. R. and A. SenGupta (2001), Topics in Circular Statistics, World Scientific, London, 2001.

Johnson, R. A. and T. E. Wehrly (1977), "Measures and models for angular correlation and angular-linear correlation", Journal of the Royal Statistical Society, 39, 222-29.

Kaiser R. and A. Maravall (2001), Measuring Business Cycles in Economic Time Series, 2001, Springer Verlag, Heidelberg.

Leibfritz, W. and W. Nierhaus (1993), "Westdeutsche Wirtschaft: Wie tief ist die Rezession?", ifo Schnelldienst 46(7), 10-15.

Mardia, K.V. (1976), "Linear-circular correlation coefficients and rhythmometry", Biometrika, 63, 403-05.

Mardia, K. V. and J. T. Kent, J. M. Bibby (2000), Multivariate Analysis, Academic Press, London.

Mills, T. C. (2003), Modelling Trends and Cycles in Economic Time Series, Palgrave Macmillan, Basingstoke.

Moore G. and J. Shiskin (1967), "Indicators of Business Expansions and Contractions", NBER, Occasional Paper 1003, New York.

OECD (2010) Business Cycle Clock, http://stats.oecd.org/mei/bcc/default.html,

Oltmanns, E. (2009), "Das Bruttoinlandsprodukt im Konjunkturzyklus", Wirtschaft und Statistik 10/2009, 963-69.

Ruth, V. and B. Schouten, R. Wekker (2005) "The Statistics Netherlands' Business Cycle Tracer. Methodological aspects; concept, cycle computation and indicator selection", Statistics Netherlands report 2005-MIC-44.

Statistisches Bundesamt (2010), Erläuterungen zum Konjunkturmonitor, http://www.destatis.de/jetspeed/portal/cms/Sites/destatis/Internet/DE/Content/Statistiken/Zeitrei hen/Konjunkturmonitortabellen/KonjunkturmonitorErlaeuterungen\%2Cproperty\%3Dfile.pdf.

Zarnowitz, V. (1992), Business Cycles, Theory, History, Indicators, and Forecasting, The University of Chicago Press, Chicago. 


\section{CESifo Working Paper Series}

for full list see www.cesifo-group.org/wp

(address: Poschingerstr. 5, 81679 Munich, Germany, office@cesifo.de)

3115 John Beirne, Guglielmo Maria Caporale and Nicola Spagnolo, Liquidity Risk, Credit Risk and the Overnight Interest Rate Spread: A Stochastic Volatility Modelling Approach, July 2010

3116 M. Hashem Pesaran, Predictability of Asset Returns and the Efficient Market Hypothesis, July 2010

3117 Dorothee Crayen, Christa Hainz and Christiane Ströh de Martínez, Remittances, Banking Status and the Usage of Insurance Schemes, July 2010

3118 Eric O’N. Fisher, Heckscher-Ohlin Theory when Countries have Different Technologies, July 2010

3119 Huw Dixon and Hervé Le Bihan, Generalized Taylor and Generalized Calvo Price and Wage-Setting: Micro Evidence with Macro Implications, July 2010

3120 Laszlo Goerke and Markus Pannenberg, 'Take it or Go to Court' - The Impact of Sec. 1a of the German Protection against Dismissal Act on Severance Payments -, July 2010

3121 Robert S. Chirinko and Daniel J. Wilson, Can Lower Tax Rates be Bought? Business Rent-Seeking and Tax Competition among U.S. States, July 2010

3122 Douglas Gollin and Christian Zimmermann, Global Climate Change and the Resurgence of Tropical Disease: An Economic Approach, July 2010

3123 Francesco Daveri and Maria Laura Parisi, Experience, Innovation and Productivity Empirical Evidence from Italy's Slowdown, July 2010

3124 Carlo V. Fiorio and Massimo Florio, A Fair Price for Energy? Ownership versus Market Opening in the EU15, July 2010

3125 Frederick van der Ploeg, Natural Resources: Curse or Blessing?, July 2010

3126 Kaisa Kotakorpi and Panu Poutvaara, Pay for Politicians and Candidate Selection: An Empirical Analysis, July 2010

3127 Jun-ichi Itaya, Makoto Okamura and Chikara Yamaguchi, Partial Tax Coordination in a Repeated Game Setting, July 2010

3128 Volker Meier and Helmut Rainer, On the Optimality of Joint Taxation for NonCooperative Couples, July 2010

3129 Ryan Oprea, Keith Henwood and Daniel Friedman, Separating the Hawks from the Doves: Evidence from Continuous Time Laboratory Games, July 2010 
3130 Mari Rege and Ingeborg F. Solli, The Impact of Paternity Leave on Long-term Father Involvement, July 2010

3131 Olaf Posch, Risk Premia in General Equilibrium, July 2010

3132 John Komlos and Marek Brabec, The Trend of BMI Values by Centiles of US Adults, Birth Cohorts 1882-1986, July 2010

3133 Emin Karagözoğlu and Arno Riedl, Information, Uncertainty, and Subjective Entitlements in Bargaining, July 2010

3134 John Boyd, Gianni De Nicolò and Elena Loukoianova, Banking Crises and Crisis Dating: Theory and Evidence, July 2010

3135 Michael R. Baye, Dan Kovenock and Casper G. de Vries, The Herodotus Paradox, July 2010

3136 Martin Kolmar and Hendrik Rommeswinkel, Group Contests with Complementarities in Efforts, July 2010

3137 Carolina Manzano and Xavier Vives, Public and Private Learning from Prices, Strategic Substitutability and Complementarity, and Equilibrium Multiplicity, July 2010

3138 Axel Löffler, Gunther Schnabl and Franziska Schobert, Inflation Targeting by Debtor Central Banks in Emerging Market Economies, July 2010

3139 Yu-Fu Chen and Michael Funke, Global Warming and Extreme Events: Rethinking the Timing and Intensity of Environmental Policy, July 2010

3140 Lawrence M. Kahn, Labor Market Policy: A Comparative View on the Costs and Benefits of Labor Market Flexibility, July 2010

3141 Ben J. Heijdra, Jochen O. Mierau and Laurie S.M. Reijnders, The Tragedy of Annuitization, July 2010

3142 Erkki Koskela, Outsourcing Cost and Tax Progression under Nash Wage Bargaining with Flexible Outsourcing, July 2010

3143 Daniel Osberghaus and Christiane Reif, Total Costs and Budgetary Effects of Adaptation to Climate Change: An Assessment for the European Union, August 2010

3144 Philip E. Graves, Benefit-Cost Analysis of Environmental Projects: A Plethora of Systematic Biases, August 2010

3145 Sabrina Di Addario and Daniela Vuri, Entrepreneurship and Market Size. The Case of Young College Graduates in Italy, August 2010

3146 Shoshana Amyra Grossbard and Alfredo Marvăo Pereira, Will Women Save more than Men? A Theoretical Model of Savings and Marriage, August 2010 
3147 Jarko Fidrmuc, Time-Varying Exchange Rate Basket in China from 2005 to 2009, August 2010

3148 Ilja Neustadt and Peter Zweifel, Is the Welfare State Sustainable? Experimental Evidence on Citizens' Preferences for Redistribution, August 2010

3149 Marcus Dittrich and Andreas Knabe, Wage and Employment Effects of Non-Binding Minimum Wages, August 2010

3150 Shutao Cao, Enchuan Shao and Pedro Silos, Fixed-Term and Permanent Employment Contracts: Theory and Evidence, August 2010

3151 Ludger Woessmann, Cross-Country Evidence on Teacher Performance Pay, August 2010

3152 Lorenzo C. G. Pozzi, Casper G. de Vries and Jorn Zenhorst, World Equity Premium Based Risk Aversion Estimates, August 2010

3153 Volker Grossmann, Thomas M. Steger and Timo Trimborn, Dynamically Optimal R\&D Subsidization, August 2010

3154 Alexander Haupt, Tim Krieger and Thomas Lange, A Note on Brain Gain and Brain Drain: Permanent Migration and Education Policy, August 2010

3155 António Afonso and Christophe Rault, Long-run Determinants of Sovereign Yields, August 2010

3156 Franziska Tausch, Jan Potters and Arno Riedl, Preferences for Redistribution and Pensions. What can we Learn from Experiments?, August 2010

3157 Martin Kolmar and Andreas Wagener, Inefficient Group Organization as Optimal Adaption to Dominant Environments, August 2010

3158 Kai Carstensen, Klaus Wohlrabe and Christina Ziegler, Predictive Ability of Business Cycle Indicators under Test: A Case Study for the Euro Area Industrial Production, August 2010

3159 Horst Rottmann and Timo Wollmershäuser, A Micro Data Approach to the Identification of Credit Crunches, August 2010

3160 Philip E. Graves, Appropriate Fiscal Policy over the Business Cycle: Proper Stimulus Policies Can Work, August 2010

3161 Michael Binder and Marcel Bluhm, On the Conditional Effects of IMF Program Participation on Output Growth, August 2010

3162 Michael Binder, Qianying Chen, and Xuan Zhang, On the Effects of Monetary Policy Shocks on Exchange Rates, August 2010

3163 Felix J. Bierbrauer, On the Optimality of Optimal Income Taxation, August 2010 
3164 Nikolaus Wolf, Europe's Great Depression - Coordination Failure after the First World War, September 2010

3165 Dan Kovenock and Brian Roberson, Conflicts with Multiple Battlefields, September 2010

3166 Jean-Pierre Ponssard and Catherine Thomas, Capacity Investment under Demand Uncertainty. An Empirical Study of the US Cement Industry, 1994-2006, September 2010

3167 Jørgen Juel Andersen, Jon H. Fiva and Gisle James Natvik, Voting when the Stakes are High, September 2010

3168 Michael Hoel, Is there a Green Paradox?, September 2010

3169 Scott Alan Carson, Nineteenth Century US African-American and White Female Statures: Insight from US Prison Records, September 2010

3170 Gil S. Epstein, Yosef Mealem and Shmuel Nitzan, Political Culture and Discrimination in Contests, September 2010

3171 Sara Fisher Ellison, Jeffrey Greenbaum and Wallace P. Mullin, Diversity, Social Goods Provision, and Performance in the Firm, September 2010

3172 Silvia Dominguez-Martinez, Randolph Sloof and Ferdinand von Siemens, Monitoring your Friends, not your Foes: Strategic Ignorance and the Delegation of Real Authority, September 2010

3173 Marcus Dittrich and Beate Schirwitz, Union Membership and Employment Dynamics: A Note, September 2010

3174 Francesco Daveri, Paolo Manasse and Danila Serra, The Twin Effects of Globalization - Evidence from a Sample of Indian Manufacturing Firms, September 2010

3175 Florian Blöchl, Fabian J. Theis, Fernando Vega-Redondo and Eric O’N. Fisher, Which Sectors of a Modern Economy are most Central?, September 2010

3176 Dag Morten Dalen, Marilena Locatelli and Steinar Strøm, Longitudinal Analysis of Generic Substitution, September 2010

3177 Armin Falk, Stephan Meier and Christian Zehnder, Did we Overestimate the Role of Social Preferences? The Case of Self-Selected Student Samples, September 2010

3178 Christian Fahrholz and Cezary Wójcik, The Bail-Out! Positive Political Economics of Greek-type Crises in the EMU, September 2010

3179 Klaus Abberger and Wolfgang Nierhaus, The Ifo Business Cycle Clock: Circular Correlation with the Real GDP, September 2010 